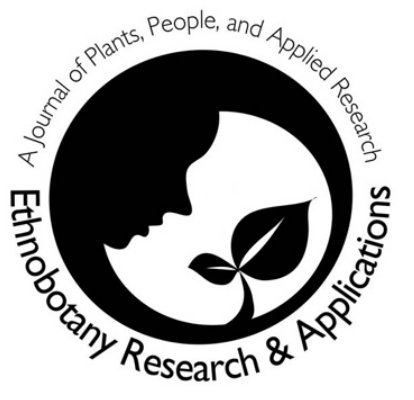

\title{
Ethnobotanical assessment of Diospyros mespiliformis Hochst. ex A. DC. (Ebenaceae) in the classified forest of Wari- Maro (Sudano-guinean area of Benin, West Africa)
}

Nicolas Atchade Samuel, Kourouma Koura and Jean C. Ganglo

Correspondence

Nicolas Atchade Samuel ${ }^{1,2^{*}}$, Kourouma Koura ${ }^{1}$ and Jean C. Ganglo ${ }^{1}$

${ }^{1}$ Laboratory of Forest Sciences, Faculty of Agricultural Sciences, University of Abomey-Calavi, Tel: +229 663637 70, email: ganglocj@gmail.com

2Direction Générale des Eaux, Forêts et Chasse, Ministère du Cadre de Vie et du Développement Durable

*Corresponding Author: n.atchade@gmail.com

Ethnobotany Research \& Applications 22:45 (2021)

\section{Research}

\begin{abstract}
Background:The ethnobotanical uses of Diospyros mespiliformis was assessed in the classified forest of Wari-Maro located in the Sudano-Guinean area of Benin. This study aimed to contribute to the sustainable management of the population of $D$. mespiliformis.
\end{abstract}

Methods. The data were collected from one hundred and seventy-nine (179) local population surveyed. Quantitative ethnobotanical indices have been calculated. A Principal Component Analysis (PCA) was used with R version 3.2.3 software to describe the relationships between the organs, the forms of use and the ethnic groups.

Results. The species is well known and differently used according to the sex, age and ethnic groups. Nagot old men revealed more knowledge (ID =0.19; IE =0.32), followed by Bariba old men (ID =0.13; IE =0.21), Nagot young men $(I D=0.12 ; \mathrm{IE}=0.20)$ and Waama men old $(I D=0.10$; IE =0.16). The ethnics Bariba and Nagot use the fruits, wood and roots much more than the Waama, while Waama use more leaves, bark and twigs. Bariba use more the fruits for the juice and direct consumption, the firewood, forage and decoction as forms of use, while Nagot use more technology wood, service wood and powder.

Conclusion: The ethnobotanical knowledge of $D$. mespiliformis recorded in this study will contribute to improve and disseminate its use in traditional medicine and its use as technical wood. Furthermore, strategies for its conservation have been suggested, like assisted regeneration.

Keywords: Diospyros mespiliformis, forest reserve of Wari-Maro, ethnobotany, Benin 


\section{Résumé}

Contexte. Les utilisations ethnobotaniques de Diospyros mespiliformis ont été évaluées dans la forêt classée de Wari-Maro située dans la zone soudano-guinéenne du Bénin. Cette étude vise à contribuer à la gestion durable des populations de $D$. mespiliformis.

Méthodologie. Les données ont été collectées à partir d'une enquête de cent soixante-dix-neuf (179) personnes des villages riverains. Des indices ethnobotaniques quantitatifs ont été calculés et l'Analyse en Composantes Principales (ACP) a été utilisée grâce au logiciel $\mathrm{R}$ version 3.2.3 pour décrire les relations entre les organes, les formes d'usage et les groupes ethniques.

Résultats. L'espèce est bien connue et diversement utilisée selon le sexe, l'âge et l'ethnie. Les vieux ou les vieilles Nagot détiennent plus de connaissances (ID =0,19; IE =0,32), suivis des vieux Bariba $(I D=0,13 ; \mathrm{IE}=0,21)$, des jeunes hommes Nagot (ID =0,12; IE =0,20) puis des vieux Waama (ID =0,10; IE =0,16). Les Bariba et Nagot utilisent beaucoup plus les fruits, les bois et les racines tandis que les Waama accordent plus d'importance aux feuilles, à l'écorce et aux brindilles. Les Bariba utilisent plus les formes d'usage «jus de fruit», "consommation directe des fruits», «bois de feu», « ourrage» et «décoction» alors que les Nagot utilisent plus le bois d'œuvre, le bois de service et la poudre.

Conclusion.Les connaissances ethnobotaniques recensées sur D. mespiliformis dans cette étude sont utiles pour mieux comprendre ses utilisations en médecine traditionnelle et comme bois d'œuvre et pour une meilleure vulgarisation. En outre, des stratégies pour sa conservation ont été suggérées, comme la régénération assistée.

\section{Background}

The forest resources are the main sources of food, income, medicine, and ecosystemic goods and services for rural people (FAO 2014, Hounkpèvi et al. 2011). Indeed, the anthropogenic pressures on these forest resources due to population growth are becoming more and more important. The percentage of the area covered by forest in the world has decreased in three decades, from $32.5 \%$ in 1990 to $30.8 \%$ in 2020 . This represents a net loss of 178 million hectares of forest (FAO \& PNUE 2020). The deforestation increased mainly in tropical forests due to the strong link between people's economic activities and their need in land (De Sy et al. 2019). Carpenter et al. (2001) estimated that an adaptation strategy, which increases food security at a given period, could act negatively in the resilience at another period. Moreover, in tropical countries where poor people' livelihoods depend strongly on forest resources, the exploitation is still done without any respect of management plans. Benin is one of those countries. It is located in the "Dahomey Gap » and characterized by more sparse savannas and some massive forests (Glèlè Kakaï et al. 2008).

The forests size in the protected areas in Benin decreased from 5761000 ha in 1990 to 4561000 ha in 2010 with an estimated losses at $20.82 \%$ during this period i.e. $1.04 \%$ per year (FAO 2010). This fact increases to this date because forest exploitation is still done without any respect of the sustainable management rules. The harvest of the valuable species threaten seriously the country' phylogenetic resources. One of main consequences of the pressure on forest resources is the scarcity of the populations of valuable species such as Khaya senegalensis and Afzelia africana (Ahoyo et al. 2018). The scarcity of those valuable species leads the need of people to other species able of providing timber (Glèlè Kakaï \& Sinsin 2008) such as Diospyros mespiliformis.

Diospyros mespiliformis is commonly called "Jackal berry or African ebony" (Ebbo et al., 2020) and belongs to the plant family, Ebenaceae. In Benin, the tree is popularly known in Yoruba as Igidudu, in Batonu as Mwibu and in Fongbe as Gunaga. Its leaves are simple and alternate in arrangement and dark green in coloration. Its height varies between 15 and $50 \mathrm{~m}$ (Chivandi \& Erlwanger 2011). The tree is dioecious, its flowers appear in the months of April and May, and the matured fruits are large yellow berries (Dangoggo et al., 2012). The tree has a black or grey-black bark (Palgrave 1981), white flowers and reproduce itself by seeds, suckering and layering (Janick \& Paull 2008). Ethnobotanical application of different parts of the tree has been reported. It is used in traditional medicine to treat some illnesses such as sleepiness illness, malaria, cough, inflammation, cardiovascular diseases, cancer, arthritis (Olanlokun et al. 2021, Adzu et al. 2002, Luka et al. 2014, Simopoulos 1999). D. mespiliformis also has edible fruits widely consumed by people in penury times (Chivandi \& Erlwanger 2011).

Despite the uses of $D$. mespiliformis described above in other countries, the species is little studied in Benin. According to Daanon et al. (2021), the species is relatively neglected scientifically in Benin. These authors studied 
the determinants of the ethnobotanical uses of $D$. mespiliformis without characterizing these uses or addressing the diseases treated. D. mespiliformis populations will be threatened whether their management plan is not developed and implemented. Thus, the data collection from local population's knowledge about the complete ethnobotanical uses of this species is needful for helping to its sustainable management. The ethnobotany is known for being the investigations of plants used by indigenous people for daily needs.

Then, through ethnobotanical approach, this paper aims to identify the main uses of $D$. mespiliformis by the local population of the forest of Wari-Maro to prevent or face all its threats not yet known such as the massive use of wood.

\section{Materials and Methods}

\section{Study area}

The study was carried out within the forest of Wari-Maro (WMF) localized in the center of Benin, between $8^{\circ} 80^{\prime}-$ $9^{\circ} 10^{\prime}$ of North latitude and $1^{\circ} 55^{\prime}-2^{\circ} 25^{\prime}$ of East longitude. It is in the sudano-guinean transition zone of White (1983) (Figure 1). According to Aubréville (1970), it corresponds to the phytogeographical transition zone of guineosudanian and constituted with the classified forests of Monts Kouffè, the latest dense driest forests which act against desertification protrusion and surface water regulation in the principal area of Oueme basin, the longest watercourse of Benin (450 km). The Forest of Wari-Maro covers 120686 ha with 50057 ha of clear forests and 56 088 ha of woody savannah (PAMF, 2007).

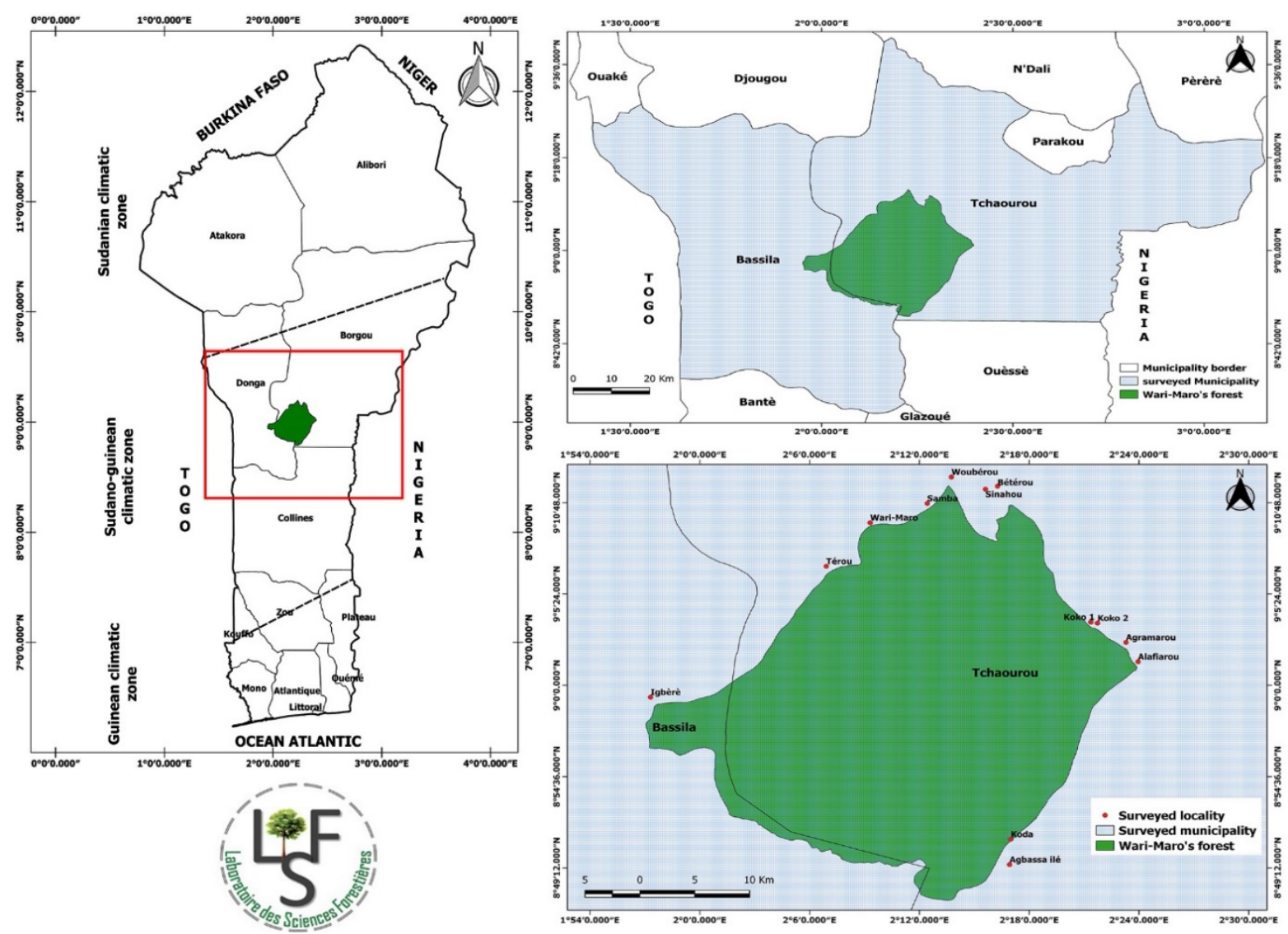

Figure 1. Location of the classified forest of Wari-Maro

The climate is Soudanian humid with two seasons in length. Some valuable species such as Pterocarpus erinaceus Poir, Afzelia africana Sm., Daniellia oliveri (Rolfe) Hutch. \& Dalziel, Isoberlinia doka Craib \& Stapf, Burkea africana Hook, Diospyros mespiliformis are the characteristic species of this zone.

This forest formerly under traditional management have been classified in November $25^{\text {th }}, 1955$. Thus, it seems more protected although its inhabitants conserve its user right on these resources. But illicit tree exploitation and extensive agricultural systems caused serious damage to this forests integrity. 
The local populations of this forest were estimated at 77000 (INSAE 2016) and they are mainly farmers, beekeepers, forests exploitants, hunters and fishermen. The sampled villages were Agramarou, Alafiarou, Banigri, Bétérou, Koda, Koko and Samba. The last one is not too close to the forest, but it was selected due to its socio-linguistic particularity.

\section{Data collection}

A first survey was conducted before the study to locate active practicing herbalists with traditional knowledge and expertise regarding local medicinal plants in the investigated areas. The local politico-administrative authorities helped to achieve this. The Code of Ethics of the International Society of Ethnobiology (ISE, 2008) was strictly followed, and the purpose of the study was explained before conducting the interviews. A verbal informant consent was obtained from the participants, who were assured about confidentiality and anonymity. A cordial relationship was established with the informants at the beginning of the study. The informants were interviewed after introducing and explaining the purpose of the survey.

Prior to data collection, a pre-sample was done in order to assess the $p$ rate of local population of these areas who used D. mespiliformis regularly. After that, Dagnelie (1998) formula was used to determinate the suitable size of sampled people per village; this formula is:

$$
\mathrm{N}=\frac{\mathrm{U}_{1-\frac{\alpha}{2}}^{2} \times \mathrm{p}(1-\mathrm{p})}{\mathrm{d}^{2}}
$$

$d$ is the error of the estimation and fixed at $8 \%, U_{1-\alpha / 2}^{2}=1,96$, normal law value obtained from the standard table of normal law distribution with $\alpha=0,05$ and $p$ is the percentage of inhabitants who used $D$. mespiliformis regularly; the sample size $(\mathrm{N})$ was 179 . These 179 respondents were selected from the 7 villages in the neighbourhood of the forest classified as Agramarou (28), Alafiarou (35), Banigri (21), Bétérou (35), Koda (28), Koko (21), Samba (11).

Individual semi-structured interviews and focus group discussions were carried out simultaneously during three months by two investigators' teams in the villages. After informants socio-demographic data recorded, ethnobotanical data were collected about the categories of use (food, medicine, forage, fuel wood, Vegetal brush, cultural), the organ used (roots, bark, fruits, leaves, flowers) and the mode of administration (powder, decoction, etc).

\section{Data analysis}

For ethnobotanical data analysis, the following indices were calculated: the interviewee diversity value (ID); the interviewee equitability value (IE); the consensus value for plant parts (CPP); the use diversity value (UD); the use equitability value (UE) and the consensus value for the form of use (CMU).

Table 1 provides a detailed explanation of each index. These parameters indicate how the species is used and how the knowledge of these uses is distributed among the interviewees (Table 1) (Koura et al. 2011).

\section{Table 1. Indices of knowledge and uses calculated for Diospyros mespiliformis}

\section{Index}

Interviewee diversity value

(ID)

$I D=U x / U t$

Interviewee equitability

value (IE)

$\mathrm{IE}=\mathrm{ID} / \mathrm{IDmax}$

Consensus value for plant

parts (CPP)

$\mathrm{CPP}=\mathrm{Px} / \mathrm{Pt}$

Use diversity value (UD)

$\mathrm{UD}=\mathrm{Ucx} / \mathrm{Uct}$

\section{Calculation}

ID, number of uses-citations by a given interviewee $(\mathrm{Ux})$ divided by the total number of uses (Ut)

IE, interviewee diversity value (ID) divided by this index's maximum value (IDmax)

CPP, number of times a given plant part was cited $(\mathrm{Px})$ divided by the total number of citations of all parts (Pt) UD, number of indications recorded by category (Ucx) divided by the total number of indications for all categories (Uct)

\section{Description}

Measures how many interviewees used Parkia biglobosa and how its uses are distributed among the interviewees

Measures the degree of homogeneity of the interviewee's knowledge

Measures the degree of agreement among interviewees concerning the plant part used

Measures the importance of the use categories and how they contribute to the total value of uses 
Use equitability value (UE)

UE $=$ UD/UDmax

Consensus value for the

form of use (CMV)

$\mathrm{CMV}=\mathrm{Mx} / \mathrm{Mt}$
UE, use-diversity value (UD) divided by the index'smaximum value (UDmax)

CMV, number of citations for a given form of use (Mx) divided by the total number of citations for all forms (Mt)
Measures the degree of homogeneity of knowledge about use categories Measures the degree of agreement among interviewees concerning the form of use of Diospyros mespiliformis

\section{Results}

\section{Diversity knowledge of Diopyros mespilformis}

All interviewees use $D$. mespiliformis. The Kruskal-Wallis rank sum test shows a significant difference between the Interviewee diversity value and Use Equitability value. Thus, the knowledge about this species usage varied strongly within the people (Table 2). In other words, a part of surveyed holds a wide knowledge about this species uses. The values obtained for these indexes are low $(<0.50)$. Men use the species more than women $(\mathrm{ID}=0.37 ; \mathrm{IE}=0.62)$ than women (ID =0.12; IE =0.21). When age was considered, nagot old men have the highest knowledge (ID = 0.19 ; IE = 0.32) followed by bariba old men (ID = 0.13; IE = 0.21), nagot young men (ID = $0.12 ; \mathrm{IE}=0.20$ ) and waama old men (ID =0.10; IE =0.16). Within the women group, nagot young women (ID =0.06; IE $=0.10)$ were the most acknowledgeable.

Table 2. People' knowledge about $D$. mespiliformis use following age and sex.

\begin{tabular}{|c|c|c|}
\hline \multirow{3}{*}{$\begin{array}{l}\text { Total number of interviees } \\
\text { Number of cited specific usages }\end{array}$} & \multicolumn{2}{|l|}{179} \\
\hline & \multicolumn{2}{|l|}{47} \\
\hline & ID (skweeness) & IE (skweeness) \\
\hline Total & $0.38(0.12) d$ & $0.64(0.19) d$ \\
\hline Total for women & $0.12(0.08) a b c$ & $0.21(0.13) a b c$ \\
\hline Bariba Women & $0.05(0.07) a b c$ & $0.09(0.12) a b c$ \\
\hline Bariba Women < 40 & $0.04(0.07) a b c$ & $0.07(0.12) a b c$ \\
\hline Bariba Women $\geq 40$ & $0.02(0.03) a b$ & $0.03(0.05) a b$ \\
\hline Nagot Women & $0.07(0.08) a b c$ & $0.12(0.13) a b c$ \\
\hline Nagot Women < 40 & $0.06(0.08) a b c$ & $0.10(0.14) a b c$ \\
\hline Nagot Women $\geq 40$ & $0.02(0.03) a b$ & $0.03(0.05) a b$ \\
\hline Waama Women & $0.05(0.06) a b c$ & $0.08(0.10) a b c$ \\
\hline Waama Women < 40 & $0.003(0.01) \mathrm{a}$ & $0.01(0.01)$ a \\
\hline Waama Women $\geq 40$ & $0.05(0.06) a b c$ & $0.08(0.10) a b c$ \\
\hline Others Women & $0.02(0.06) a b$ & $0.04(0.09) a b$ \\
\hline Others Women < 40 & $0.01(0.03) a b$ & $0.02(0.05) a b$ \\
\hline Others Women $\geq 40$ & $0.02(0.06) a b$ & $0.04(0.09) a b$ \\
\hline Total for Men & $0.37(0.12) \mathrm{d}$ & $0.62(0.20) \mathrm{d}$ \\
\hline Bariba Men & $0.16(0.16) a b c$ & $0.26(0.27) a b c$ \\
\hline Bariba Men < 40 & $0.08(0.11) a b c$ & $0.13(0.18) a b c$ \\
\hline Bariba Men $\geq 40$ & $0.13(0.13) a b c$ & $0.21(0.22) a b c$ \\
\hline Nagot Men & $0.21(0.15) \mathrm{c}$ & $0.35(0.25) c$ \\
\hline Nagot Men < 40 & $0.12(0.11) a b c$ & $0.20(0.19) a b c$ \\
\hline Nagot Men $\geq 40$ & $0.19(0.13) b c$ & $0.32(0.23) b c$ \\
\hline Waama Men & $0.10(0.12) a b c$ & $0.16(0.21) a b c$ \\
\hline Waama Men < 40 & $0.06(0.07) a b c$ & $0.10(0.12) a b c$ \\
\hline Waama Men $\geq 40$ & $0.10(0.12) a b c$ & $0.16(0.21) a b c$ \\
\hline Others Men & 0.05 (0.09) abc & $0.09(0.16) a b c$ \\
\hline Others Men < 40 & $0.04(0.07) a b c$ & $0.07(0.12) a b c$ \\
\hline Others Men $\geq 40$ & $0.04(0.06) a b c$ & $0.06(0.11) a b c$ \\
\hline
\end{tabular}

For each parameter, values followed by same letters are not significantly different and values followed by different letters are significantly different (Kruskal-Wallis test).

\section{Use classes and subclasses}

Six use classes were widely cited for D. mespiliformis (Figure 2). The technological use was the most cited (47.22 $\%)$, whereas the weakest was medico-magic usage (1.66 \%). Other cited use classes are food (22.48 \%), forage (13.37\%), vegetal brush (12.90\%) and medicinal (2.37\%). 


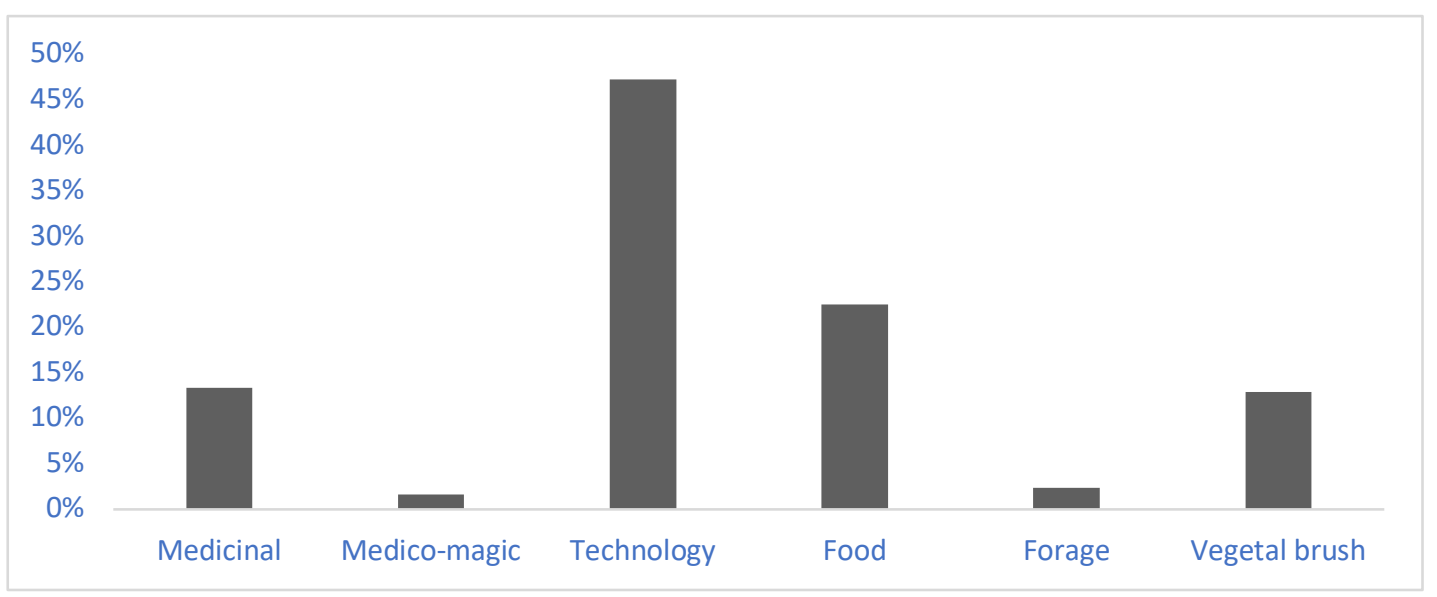

Figure 2. Use categories for D. mespiliformis

This species has edible fruits, which were consumed by people. These fruits were also mentioned sometimes in a beverage manufacturing. The wood was secondary cited for energy. For medicinal use, 29 pains or illnesses (Figure 3 ) treatment involved $D$. mespiliformis. The most cited pains and illnesses were malaria, fever, tiredness, and stomach aches. D. mespiliformis leaves were cited for livestock forage whereas the medico-magic concerned mainly women fealty, childbearing easiness, bewitchment, fighting and crop yielding.

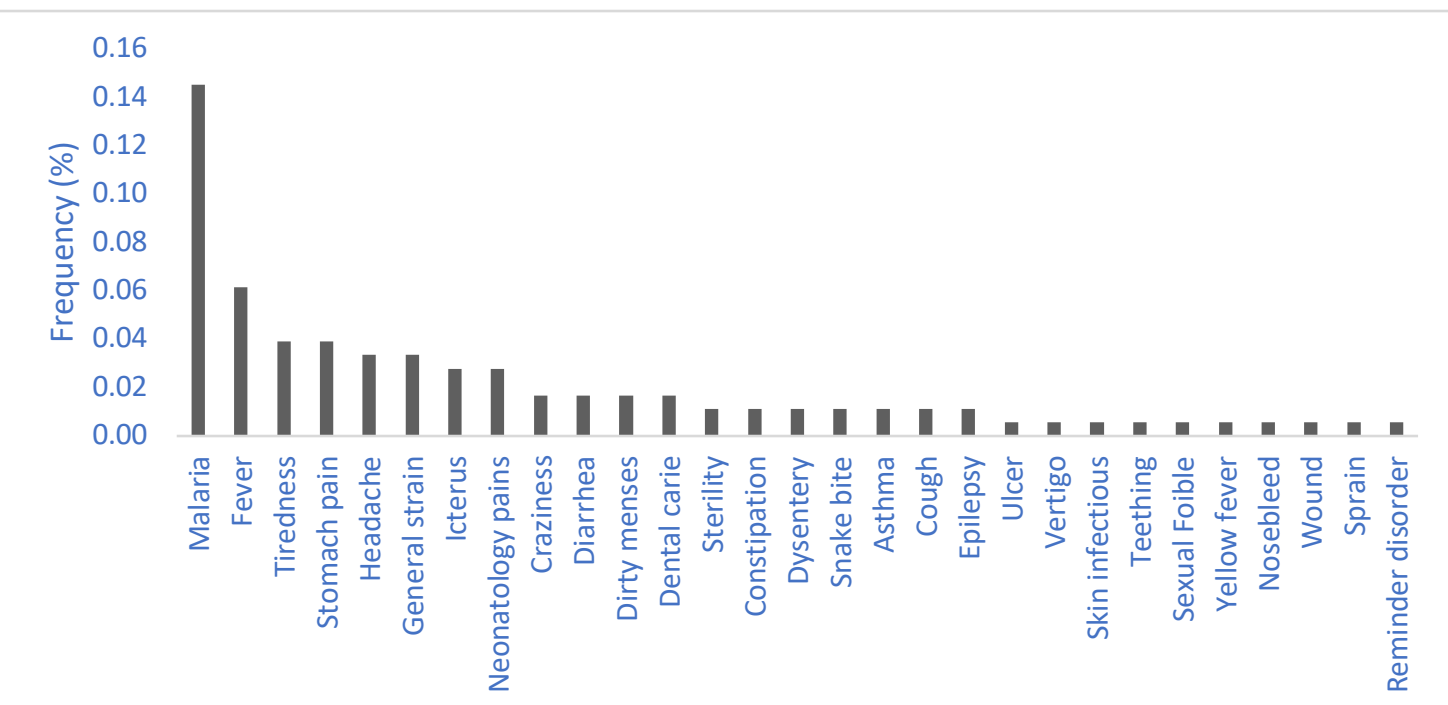

Pains/Illnesses

Figure 3. Pains/Illnesses treated with $D$. mespiliformis in traditional medicine

Whether $D$. mespiliformis was mostly used as wood and food. the use diversity values indicate that its medicinal use holds the greatest number of specific uses regardless of the considered ethnic. Contrary. the food category was very weakly diversified albeit it has mentioned by all ethnic groups. Furthermore. medico-magic and forage categories were not cited at all by other ethnics (Table 3).

Table 3. Use Diversity (UD) and the Usage Equitability (UE) values following D. mespiliformis use categories.

\begin{tabular}{lllllllll}
\hline \multirow{2}{*}{ Use Categories } & Bariba & \multicolumn{4}{c}{ Nagot } & \multicolumn{3}{c}{ Waama } \\
\cline { 2 - 9 } & UD & UE & UD & UE & UD & UE & UD & UE \\
\hline Medicinal & 0.52 & 1 & 0.70 & 1 & 0.33 & 1 & 0.42 & 1 \\
Medico-magic & 0.20 & 0.38 & 0.06 & 0.08 & 0.20 & 0.60 & - & - \\
Technology & 0.12 & 0.23 & 0.12 & 0.17 & 0.27 & 0.80 & 0.33 & 0.80 \\
Food & 0.08 & 0.15 & 0.06 & 0.08 & 0.07 & 0.20 & 0.17 & 0.40 \\
Forage & 0.04 & 0.08 & 0.03 & 0.04 & 0.07 & 0.20 & - & - \\
Vegetal brush & 0.04 & 0.08 & 0.03 & 0.04 & 0.07 & 0.20 & 0.08 & 0.20 \\
\hline
\end{tabular}




\section{Use of $\boldsymbol{D}$. mespiliformis organs}

The most used parts of these species are fruit pulp (38 \%), wood (35\%) and leaves (13\%) followed by bark (7\%). roots $(5 \%)$ and twigs $(2 \%)$. Whereas its fruits, wood, leaves and bark were significant for all ethnic groups. roots were not valued by Waama and twigs were not valued by Others ethnic groups (Yom, Zerma, Berba, Dendi, Ditamari, Fon and Lokpa) (Table 4).

Table 4. Consensual values of D. mespiliformis used parts (CPP)

\begin{tabular}{lllll}
\hline Parts & Bariba & Nagot & Waama & Others \\
\hline Roots & 0.04 & 0.07 & 0 & 0 \\
Wood & 0.36 & 0.37 & 0.30 & 0.38 \\
Bark & 0.05 & 0.07 & 0.11 & 0.06 \\
Leaves & 0.12 & 0.09 & 0.23 & 0.12 \\
Fruits & 0.41 & 0.39 & 0.30 & 0.44 \\
Twigs & 0.02 & 0.01 & 0.06 & 0 \\
\hline
\end{tabular}

The PCA performed on the consensus values of plant parts explained at $95.91 \%$ through its two first axes. the total variation of used parts of $D$. mespiliformis within the people. According to the axis's correlation with the used parts (Table 5), the bark, leaves and twigs were often used together in opposition to wood, fruits and leaves (Axis 1). The utilization of the roots seems non-dependent to other parts (Axis 2).

The projection of ethnic groups into the two first axis shows that the main autochthonous ethnics groups (Nagot, Bariba and Waama) share more within itself the knowledge about the species use than with the others (minority groups) (Figure 4).

Table 5. D. mespiliformis organs used in correlation $\left(\mathrm{R}^{2}\right)$ with the two first axis of the PCA

\begin{tabular}{lll}
\hline Plant organs & Axis 1 & Axis 2 \\
\hline Roots & -0.56 & 0.83 \\
Wood & -0.98 & -0.14 \\
Bark & 0.92 & 0.07 \\
Leaves & 0.98 & -0.19 \\
Fruits & -0.95 & -0.31 \\
Twigs & 0.95 & 0.16 \\
\hline
\end{tabular}

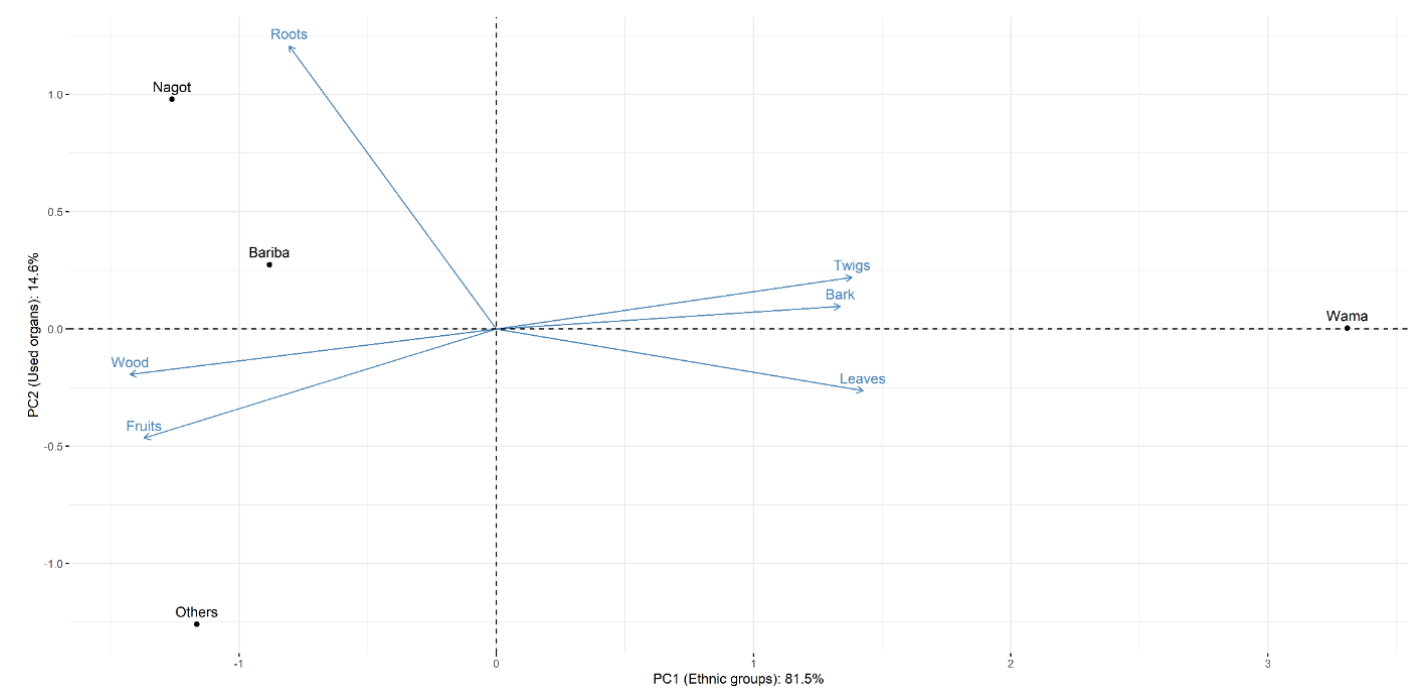

Figure 4. Projection of ethnic' groups and the organs used in the system defined by the two first axis of the PCA

\section{Use forms of $D$. mespiliformis}

Ten use forms were identified for this species. Its food use (22.04 \%) is the most important following by service $16.37 \%$ ) and technologic (16 \%) wood. Vegetal brush (14.61 \%), fuelwood (13.85\%), decoction (8.69 \%), charcoal $(2.64 \%)$, forage $(2.52 \%)$, fruit juice $(1.89 \%)$ and fruit powder (1.39\%).

According to the Consensus value for the Form of Use (CFU), food, Vegetal brush, technologic wood and energy remain the main use forms considering all ethnic groups (Table 6). 
Table 6. Consensus value for the Form of Use (CFU) de D. mespiliformis

\begin{tabular}{lllll}
\hline Use Forms & Bariba & Nagot & Waama & Others \\
\hline Fuelwood & 0.137 & 0.161 & 0.076 & 0.141 \\
Service wood & 0.137 & 0.179 & 0.174 & 0.140 \\
Technologic wood & 0.132 & 0.179 & 0.174 & 0.109 \\
Fruit Juice & 0.028 & 0.018 & - & 0.031 \\
Forage & 0.023 & 0.028 & - & 0.062 \\
Vegetal brush & 0.193 & 0.101 & 0.197 & 0.156 \\
Charcoal & - & 0.028 & 0.053 & 0.047 \\
Food & 0.260 & 0.207 & 0.197 & 0.219 \\
Decoction & 0.075 & 0.078 & 0.129 & 0.093 \\
Fruit powder & 0.014 & 0.021 & - & - \\
\hline
\end{tabular}

The two first axis of the performed PCA on the Consensus value for the Form of Use (CFU) of $D$. mespiliformis explained at $81.38 \%$ the total variation of the species use forms according to ethnics' groups. The use forms such as food, Fruit Juice, Decoction, Service wood, Fuelwood and Charcoal are often linked. They are strongly correlated to the first axis in contrary to Technologic wood. Vegetal brush and Powder which are correlated to the second axis (Table 7).

Table 7. Use forms of D. mespiliformis Correlation with PCA axis

\begin{tabular}{lll}
\hline Use forms & Axis 1 & Axis 2 \\
\hline Fuelwood & $\mathbf{0 . 8 3}$ & 0.47 \\
Service wood & $\mathbf{- 0 . 7 2}$ & $\mathbf{0 . 6 8}$ \\
Technologic wood & $\mathbf{- 0 . 6 6}$ & $\mathbf{0 . 7 1}$ \\
Fruit juice & $\mathbf{0 . 9 6}$ & -0.17 \\
Forage & $\mathbf{0 . 6 8}$ & -0.20 \\
Vegetal brush & -0.23 & $\mathbf{- 0 . 7 9}$ \\
Charcoal & $\mathbf{- 0 . 7 1}$ & -0.20 \\
Direct consummation (food) & $\mathbf{0 . 7 9}$ & -0.26 \\
Decoction & $\mathbf{0 . 9 1}$ & -0.41 \\
Powder & 0.46 & $\mathbf{0 . 8 3}$ \\
\hline
\end{tabular}

The projection of the ethnics' groups onto the PCA axis systems constituted by these use forms revealed that Bariba and Waama are more linked to the first axis whereas Nagot is correlated to the second axis, use more $D$. mespiliformis as Technologic wood, Vegetal brush and Powder (Figure 5).

The Diversity Index of Simpson computed for ethnic groups show high values which trend towards interviewed number per ethnic group (Table 9). Indeed, each interviewee knows at least one use form of $D$. mespiliformis. The knowledge about $D$. mespiliformis uses is well shared among the ethnic groups as showed in Table 8.

Table 8. Diversity Indices of Simpson per ethnic group

\begin{tabular}{lllll}
\hline Parameters & Bariba & Nagot & Waama & Others \\
\hline Interviewees number per ethnic group & 55 & 84 & 26 & 14 \\
Diversity Index of Simpson (1/D) & 27.35 & 41.33 & 21.38 & 12 \\
\hline
\end{tabular}

\section{Discussion}

D. mespiliformis is well known by the local populations of the forest of Wari-Maro who use it for various needs. The knowledge about endogenous use of natural resources is essential to set conservation strategies (AchiganDako et al. 2011). The Kruskal-Wallis rank sum test performed on diversity and equitability values of interviewees showed that this species is used differently according to ethnic groups, sex and age. The same fundings were done by Daanon et al. (2021) for this species in the northern of Benin and by Ahoyo et al. (2018) for the same area considering all useful woody species, Koura et al. (2011) on Parkia biglobosa; Fandohan et al. (2010) on Tamarindus indica, De Caluwé et al. (2009), Assogbadjo et al. (2006 and 2008) on Adansonia digitata and Assogbadjo et al. (2010) on Caesalpinia bonduc. Therefore, D. mespiliformis is considered as a heritage of the local populations settled around the forest of Wari-Maro. Such related knowledge is characteristic of the local populations according to Lokonon et al. (2021). 


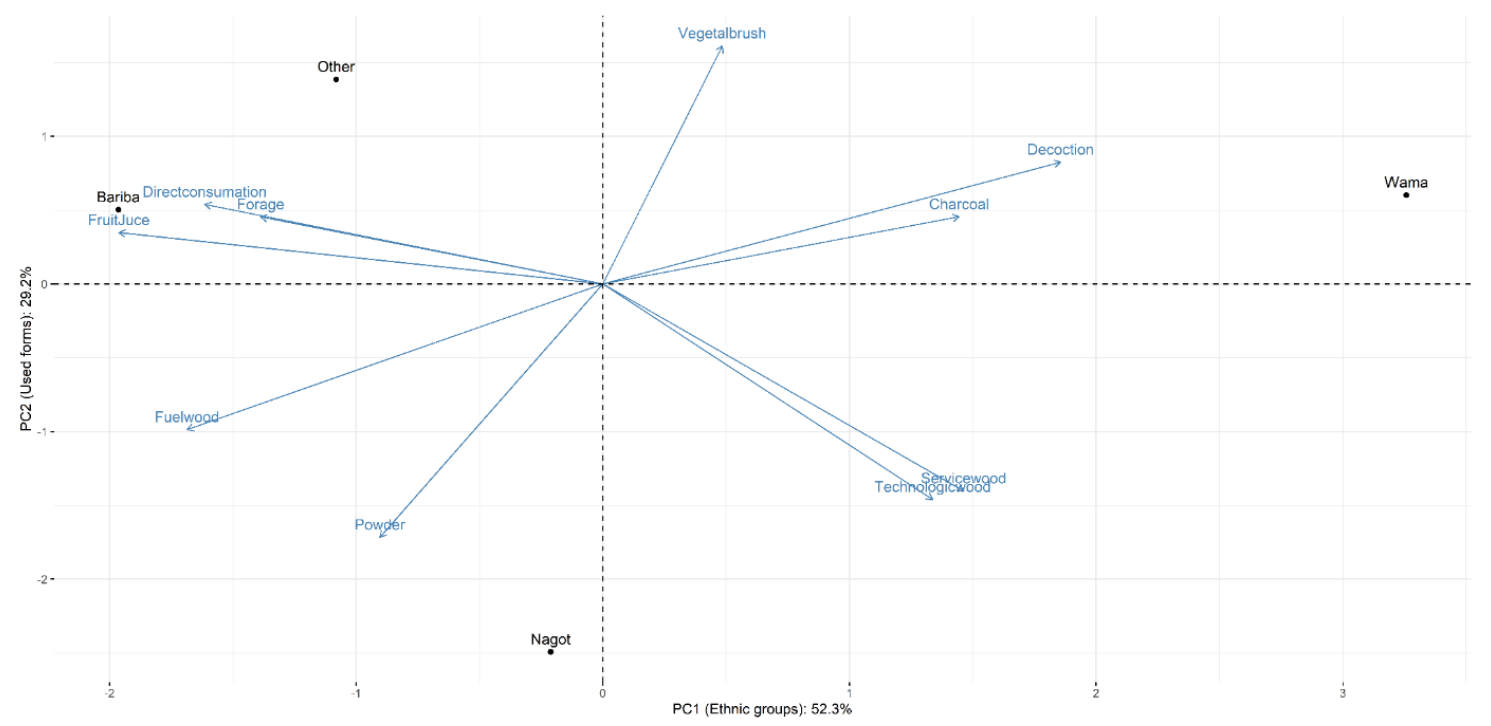

Figure 5. Projection of ethnic' groups onto PCA axis according to D. mespiliformis use forms

Six use categories were identified for the species, which include traditional medicine, medico-magic, wood, food, forage and vegetal brush. The different uses of its organs make it species with multiple uses. Its predominant use is the wood. Indeed, its wood is used as technologic and service for building or tools manufacturing. $D$. mespiliformis wood is also used as fuel wood or for charcoal production. Duangjai et al. (2009) found the similar conclusions for the species of Diospyros genera (D. celebica. D. crassiflora. D. dendo. D. ebenum. D. melanoxylon. $D$. mollis and $D$. reticulata) which was qualified for the good quality of its wood. The importance given by the population to the wood of $D$. mespiliformis is undoubtedly an unfavorable factor for the conservation of the species. Indeed, the exploitation of timber for the manufacture of certain objects requires the felling of the whole tree that can harm the survival of the tree. This result was found on Balanites aegyptiaca by Abdou Habou et al. (2020). Unfortunately, no domestication approach known from the surveyed was recorded during the field investigation.

D. mespiliformis nutritional use as food is also too important. In this frame, Chivandi \& Erlwanger (2011) shared that its fruits are wide consummed in Nigeria. The fruits hold a good quantity of soluble sugar, a potential source of energy. Campbell (1986) also cited D. mespiliformis within the three wildest fruits species consumed in Zimbabwé. This reveal a good potential in the fight against food insecurity if the species is well valorized.

The medicinal use of the species is also well known and the most diversified for the different diseases treated. This use category involve all its organs for mainly the treatment of malaria, fever and tiredness. The ethno-medicine or traditional medicine is a set of conventional practices included in the tacit knowledge of a social group. The oral transmission of ethnobotanical information through generations to generation aims at solving health problems (Khalid et al. 2015). The World Health Organization (WHO) emphasizes the significance of the local traditional medicine, hence a great majority of people (over $80 \%$ ) in the rural areas of developing countries is still dependent on these medicines at the first step in their healthcare (Rindi et al. 2014; Goleniowski et al. 2006). Thereby, D. mespiliformis medicinal uses were widely reported in this study and was claimed by other authors such as Mohammed et al. (2009) who shared the wide use of its bark, roots, and leaves; and Ebbo et al. (2014) who insisted on its use against fever and syphilis. The high values obtained for the Simpson Diversity Indice imply that each local population knows at least one use of the target species. These results explain the strong pressure that the population gives on this species. According to Abdou Habou et al. (2020), the higher the number of use categories of a plant is, the more the species is solicited and the more pressure on it increases.

Those uses must be involved in the species conservation strategies with the collaboration of local populations (Monteiro et al. 2006). But the widespread use of the wood of this species due to its quality induced several threats on its population viability. Indeed, the mature trees, which provide seeds for the species regeneration, are selected for wood harvesting. To resolve this problem, Albuquerque and Andrade (2002) and Monteiro et al. (2006) show 
the need to develop sustainable management of threatened plants species which must involve both scientists and traditional dignitaries.

For instance, the wide use of this species with many use categories can cause serious damages on its availability in the wild state, especially in the forest reserve of Wari-Maro.

For the restoration of this valuable species, the natural regeneration must be assisted through seedling location and adventitious removal. The forest settlement must be opened (selective clearing) to allow light entrance in the undergrowth to help the seeds germination and growing (Geldenhys 2010). In this sense, exploitable trees could be taken away in the dense areas of the forest while maintaining some ones to serve as seed trees. Moreover, $D$. mespiliformis could be incorporated in planting operations with nursery plants. The seeds could be safeguarded against predators and vegetation fires. This species was already found to be threatened at Northwestern Benin in West Africa by Agbani et al. (2018).

\section{Conclusions}

All parts of $D$. mespiliformis are used to satisfy the daily needs, especially within traditional medicine and the wide consumption of its fruits that induce mainly the seeds destruction. The great technologic quality of its wood is a source of its selective sampling by loggers, and thus jeopardized the wild population. Moreover, its domestication and reproduction remain problematic.

The ethnic was found as highly discriminator of the knowledge associated to $D$. mespiliformis use, in relation with the profession. Indeed, Nagot, who were strongly involved in the technological use of the species may be trained for its sustainable harvest. Furthermore, its domestication may be targeted.

For this species restoration and conservation, further research must assess its population dynamic, its silviculture, the quality of its preferred soils and the impact of other species on its population trend. The forests inhabitants must be strongly involved in those studies. Then, their traditional knowledge could be valorized using the best strategies for the species sustainability.

\section{Declarations}

List of abbreviations:

CMV: Consensus value for the Form of Use; CPP: Consensus value of Plants Parts; FAO: Food and Agriculture Organization of United Nations; ID: Interviewee diversity value; IE: Interviewee equitability value; INSAE: National Institute of Statistics and Economic Analysis; PCA: Principal Component Analysis; UD: Use Diversity Value; UE: Use Equitability value

Ethics approval and consent to participate: All interviewees were totally consenting and gave their agreement to participate in investigations.

Consent for publication: Not applicable

Availability of data and materials: The data collected and processed are available from the authors and could bring them if required by the review

Competing interests: The authors declare no conflict of interest

Funding: This research has been funded by scholarship program of the Belgian Technical Cooperation (CTB) and the Global Biodiversity Information Facility (GBIF) for data collection.

Authors' contributions:

Nicolas Atchadé Samuel: Study design. ethnobotany surveys conduction. active participation in structuring of the methodology. manuscript writing. data analysis and interpretation. Kourouma Koura: Study conception and supervision. Contribution to the study design Methodology description. Jean Cossi Ganglo: Work supervising. contribution to Methodology. authorizations of different institutions to conduct the surveys. manuscript improving and Review-Editing. All authors read. reviewed. and approved the manuscript.

\section{Acknowledgements}

The authors wish to express their sincere thanks to all colleagues of the laboratory of forest sciences, especially to Mr. Kingbo Armand for his inputs in the English version of the manuscript.

The authors are also grateful to all respondents from the local population who have accepted to participate in this survey. 


\section{Literature cited}

Abdou Habou MK, Rabiou H, Abdou L, Ibrahim Mamadou M, Mahamane A. 2020. Connaissances ethnobotaniques et importance socioculturelle de Balanites aegyptiaca (L.) Del. dans le Centre-Est du Niger. Afrique sScience 16(4):239-252

Achigan-Dako E, N'Danikou S, Assogba-Komlan F, Ambrose-Oji B, Ahanchede A, Pasquini M. 2011. Diversity. Geographical. and Consumption Patterns of Traditional Vegetables in Sociolinguistic Communities in Benin: Implications for Domestication and Utilization. Economic Botany 65:129-145.

Adzu B, Amos S, Muazzam I, Inyang US, Gamaniel KS. 2002. Neuropharmacological screening of Diospyros mespiliformis in mice. Journal of Ethnopharmacology 83:139-143.

Agbani PO, Kafoutchoni KM, Salako KV, Gbedomon RC, Kégbé AM, Karen H, Sinsin B. 2018. Traditional ecological knowledge-based assessment of threatened woody species and their potential substitutes in the Atakora mountain chain. a threatened hotspot of biodiversity in Northwestern Benin. West Africa. Journal of Ethnobiology and Ethnomedicine 14:21. doi: 10.1186/s13002-018-0219-6.

Ahoyo CC, Houehanou TD, Yaoitcha AS, Prinz K, Assogbadjo AE, Adjahossou CSG, Hellwig F, Houinato MRB. 2018. A quantitative ethnobotanical approach toward biodiversity conservation of useful woody species in Wari Maro forest reserve (Benin. West Africa). Environment. Development and Sustainability 15(5):2301-2320. doi: 10.1007/s10668-017-9990-0.

Assogbadjo AE, De Caluwé E, Sinsin B, Codjia J-CT, Van Damme P. 2006. Indigenous knowledge of rural people and importance of baobab tree (Adansonia digitata L.) in Benin. In Proceedings of the fourth International Congress of Ethnobotany (ICEB. 2005): 21-26 August 2005. Edited by: Füsun Ertug Z. Yeditepe. University Istanbul. Turkey. 3947.

Assogbadjo AE, Glèlè Kakaï R, Chadaré FJ, Thomson L, Kyndt T, Sinsin B, Van Damme P. 2008. FolkcClassification. perception. and preferences of Baobab products in West Africa: Consequences for Species Conservation and Improvement. Economic Botany 62(Suppl 1):74-84.

Assogbadjo AE, Glèlè Kakaï R, Adjallala FH, Azihou AF, Vodouhê GF, Kyndt T, Codjia JTC. 2010. Ethnic differences in use value and use patterns of the threatened multipurpose scrambling shrub (Caesalpinia bonduc L.) in Benin. Journal of Medicinal Plants Research 5(9):1549-1557.

Aubréville A. 1970. Flore du Cameroon : Légumineuses Cesalpinoideae. Muséum National d'histoire naturelle. Paris. $270 \mathrm{p}$.

Campbell BM. 1986. The importance of wild fruits for peasant households in Zimbabwe. Food and Nutrition. 12(1):38-44.

Carpenter S, Walker B, Anderies JM, Abel N. 2001. From metaphor to measurement: resilience of what to what? Ecosystems 4:765-781.

Chivandi E, Erlwanger KH. 2011. Potential Usage of African Ebony (Diospyros mespiliformis) Seeds in Human Health. Nuts \& Seeds in Health and Disease Prevention. doi: 10.1016/B978-0-12-375688-6.10016-7.

Daanon A, Padonou EA, Akakpo BA, Houinato M. 2021. Variabilité des utilisations de Diospyros mespiliformis Hochst suivant les facteurs sociodémographiques au Nord-Bénin. Bois et Forêts des Tropiques, 347: x-z. doi: 10.19182/bft2021.347.a

Dagnelie P. 1998. Statistique théorique et appliquée volume 2. Paris et Bruxelles. De Boeck et Larcier. 508-659.

Dangoggo SM, Hassan LG, Sadiq LS, Manga SB. 2012. Phytochemical analysis and antibacterial screening of leaves of Diospyros mespilifornis and Ziziphus spinachristi. Journal of Chemical Engineering 1(1)13-17.

De Caluwé E, De Smedt S, Assogbadjo AE, Samson R, Sinsin B, Van Damme P. 2009. Ethnic differences in use value and use patterns of Baobab (Adansonia digitata L.) in Northern Benin. African Journal of Ecology 47:433-440.

De Sy V, Herold M, Achard F, Avitabile V, Baccini A, Carter S, Clevers JGPW, Lindquist E, Maria Pereira, Verchot L. 2019. Tropical deforestation drivers and associated carbon emission factors derived from remote sensing data. Environmental Research Letters 14(9):094022. doi: 10.1088/1748-9326/ab3dc6

Duangjai S, Samuel R, Munzinger J, Forest F, Wallnofer B, Barfuss MHJ, Fischer G, Chase MW. 2009. A multi-locus plastid phylogenetic analysis of the pantropical genus Diospyros (Ebenaceae). with an emphasis on the radiation and biogeographic origins of the New Caledonian endemic species. Molecular Phylogenetics and Evolution 52:602620.

Ebbo AA, Mammam M, Suleiman MM, Ahmed A, Bello A. 2014. Preliminary Phytochemical Screening of Diospyros mespiliformis. Anatomy \& Physiology 4:156. doi: 10.4172/2161-0940.1000156

Ebbo A.A., Sani D., Suleiman M.M, Ahmad A., Hassan A.Z., 2020. Acute and sub-chronic toxicity evaluation of the crude methanolic extract of Diospyros mespiliformis Hochst ex a. Dc (Ebenaceae) and its fractions. Toxicology Reports 7:1138-1144. doi: 10.1016/j.toxrep.2020.08.028 
Fandohan B, Assogbadjo AE, Glèlè Kakaï R, Kyndt T, De Caluwé E, Codjia JTC, Sinsin B. 2010. Women's traditional knowledge. use value. and the contribution of tamarind (Tamarindus indica L.) to rural households'cash income in Benin. Economic Botany 64(3):248-258.

FAO. 2010. Evaluation des ressources forestières mondiales 2010 : Rapport principal. Etude FAO Forêt 163. Rome 2010.

FAO. 2014. Une nouvelle dynamique pour les forêts méditerranéennes. Unasylva 242. Vol. 65. 2014/1.

FAO et PNUE. 2020. La situation des forêts du monde 2020. Forêts, biodiversité et activité humaine. Rome. doi: 10.4060/ca8642fr

Goleniowski ME, Bongiovanni G, Palacio L, Nuñez C, Cantero J. 2006. Medicinal plants from the "Sierra de Comechingones". Argentina. Journal of Ethnopharmacology 107:324-341.

Glèlè Kakaï R, Sinsin B, Palm R. 2008. Etude dendrométrique de Pterocarpus erinaceus Poir. des formations naturelles de la zone soudanienne au Bénin. Agronomie Africaine 20(3):245-255.

Hounkpèvi A, Yévidé ASI, Ganglo JC, Devineau JL, Azontonde AH, Adjakidje V, Agbossou EK, De Foucault B. 2011. Structure et écologie de la forêt à Diospyros mespiliformis Hochst. ex A. DC. et à Dialium guineense Willd. de la réserve de Massi (La Lama). Bénin. Bois et forêts des tropiques 308 (2 :33-46

INSAE. 2016. Rapport du Quatrième Recensement Général de la Population et de l'Habitation. Bénin. 33 pp.

International Society of Ethnobiology. 2008. The ISE (International Society of Ethnobiology) Code of Ethics. http://www. ethnobiology.net/what-we-do/core-programs/ise-ethics-program/code-of-ethics/.

Joseh, B, George J, Mohan J. 2013. Pharmacology and traditional uses of Mimosa pudica. IJPSDR 5 (2), 41-44.

Janick J, Paull RE. 2008. Diospyros mespiliformis. In J. Janick. \& RE. Paull (eds.). The encyclopedia of fruit and nuts (pp. 337). Wallingford. UK: CABI.

Khalid R, Zia-ur-Rehman M, Mubark AK, Zahid U, Hassan JC. 2015. An ethno botanical perspective of traditional medicinal plants from the Khattak tribe of Chonthra Karak. Pakistan. Journal of Ethnopharmacology 165:251-259.

Koura K, Ganglo JC, Assogbadjo AE, Agbangla C. 2011. Ethnic differences in use values and use patterns of Parkia biglobosa in Northern Benin. Journal of Ethnobiology and Ethnomedicine 7:42.

Le S, Josse J, Husson F. 2008. FactoMineR: An R Package for Multivariate Analysis. Journal of Statistical Software 25(1):1-18.

Lokonon BE, Sodoté FE, Glèlè Kakaï R. 2021. Use of local knowledge for contributing to the conservation of Caesalpinia bonduc (L.) Roxb in southern Benin (West Africa). Global Ecology and Conservation 27 (2021) e01551. doi: 10.1016/j.gecco.2021.e01551

Luka J, Badau SJ, Mbaya AW, Gadzama JJ, Kumshe HA. 2014. Acute toxicity study and effect of prolonged administration (28 days) of crude ethanolic root extract of Diospyros mespiliformis Hochst (Ebenaceae) on clinical. haematological and biochemical parameters of albinorats. Journal of Ethnopharmacology 153:268-273.

Mohammed IE, El Nur El Bushra E, Choudhary MI, Khan SN. 2009. Bioactive natural products from two Sudanese medicinal plants Diospyros mespiliformis and Croton zambesicus. Records Natural Products 3:198-203.

Monteiro JM, Albuquerque UP, Lins Neto EMF, Araùjo EL, Amorim ELC. 2006. Use Patterns and Knowledge of Medicinal Species among Two Rural Communities in Brazil's Semi-Arid Northeast-ern Region. Journal of Ethnopharmacology 105:173-186.

Olanlokun JO, Bodede O, Prinsloo G, Olorunsogo OO. 2021. Comparative antimalarial, toxicity and mito-protective effects of Diospyros mespiliformis Hochst. ex A. DC. and Mondia whitei (Hook. f.) Skeels on Plasmodium berghei infection in mice. Journal of Ethnopharmacology, 268:113585. doi: 10.1016/j.jep.2020.113585

Palgrave KC. 1981. Trees of Southern Africa. Cape Town (p.748). Republic of South Africa: Struik Publishers.

PAMF. 2007, Plan d"Aménagement Participatif du complexe des forêts classées de Wari-Maro et des Monts Kouffé. Volume A (Partie descriptive), $267 \mathrm{p}$.

R Core Team. 2017. R: A language and environment for statistical computing. R Foundation for Statistical Computing. Vienna. Austria. URL https://www.R-project.org/.

Rindi G, Petrone G, Inzani F. 2014. The 2010 WHO Classification of Digestive Neuroendocrine Neoplasms: a Critical Appraisal four years after Its Introduction. Endocrine Pathology 25 (2):186-192.

Simopoulos AP. 1999. Essential fatty acids in health and chronic disease. The American Journal of Clinical Nutrition 70:560-569.

White F. 1983. The vegetation of Africa. A descriptive memoir to accompany the Unesco / Aetfat / Unso vegetation map of Africa UNESCO. Natural Resoures Research 356p. 